\title{
SHORT-ROTATION RYEGRASS IN OTAGO AND SOUTHLAND
}

By A. G. ELLIOTT, Fields Superintendent, Department of Agriculture, Dunedin.

\section{INTRODUCTION}

The data presented cover results from shortrotation ryegrass established over a very wide range of climate, soil, and farming conditions, Reports are based on sowings commenced in 1943 under annual rainfalls from 15 inches in Central Otago to 40 inches in Southland, and on soil types varying from light gravels of relatively low fertility, to highly productive deep alluvial deposits.

\section{DISCUSSION}

(a) Persistency and Production: It' is essential to discuss these factors in relation to local conditions and in this connection the new strain was. sown in North and Central Otago as a special purpose pasture providing early grazing and a seed crop. Under this system satisfactory grazing and a payable yield of seed have been secured from all except very low rainfall areas on light soils of low moisture holding capacity and fertility. Best results were obtained where associated clover establishment occurred and the nitrogen status of the soil was satisfactory, but in all cases recovery after harvest was the factor governing the persistency of the strain. Under low rainfall conditions on light open soils with poor clover strikes and lower than average fertility the area deteriorated rapidlv and in manv cases was ploughed up in the second season. Persistency and production are dependent on a rotational grazing system, as the sward opens up under close continuous feeding-off, especially under dry conditions. A high fertility area at Totara, North Otago, seeded 3 years in succession remained dominant short-rotation ryegrass for 5 years under cattle grazing.

In the higher rainfall districts the strain, sown with clover as a special purpose pasture, or included with other species in a general grazing area, has given very satisfactory results, particularly where soil fertility was above average. In certain districts the prolific early growth of short-rotation ryegrass in straight 
pasture mixtures has suppressed clover establishment, and the best-balanced swards have been secured' by sowing with such crops as rape, wheat, or oats following a fed-off root. crop, which ensures an adequate and immediately available supply of nitrogen. Although there are a number of areas sown with shortrotation ryegrass, and red and white clover, managed as a special purpose pasture under a system of rotational or long spells between grazing with cutting for hay or seed, the most popular use for the recent introduction is as an ingredient in the permanent pasture mixture. Here it provides very valuable early palatable feed. for calving cows and lambing ewes and has persisted for 5 to 7 years, partly by re-seeding during the seed- or hay harvest. Reports indicate that it is more susceptible to grass-grub (Odontria) attack than is perennial ryegrass, this fact being obviously demonstrated in some strain and half-paddock trials.

Data on persistency and production of shortrotation ryegrass in this territory can be summarised as follows :-

1. . Satisfactory special purpose pastures,. managed' to provide early palatable feed plus seed or hay, can be maintained for periods up to 5 years on medium to high fertility soils under reasonable rainfall. Sowing rate 20 to 25 Ib per acre' with clovers preferably following a fed-off root crop and, spring sown with rape, wheat, or oats.

2. Good results have been secured as an ingredient in a permanent pasture containing perennial ryegrass, cocksfoot, timothy, and clovers when the shortrotation ryegrass provides early palatable feed and remains in a well-managed sward for up to 5 years. The value of the strain is markedly dependent on soil fertility, particularly regarding nitrogen status and good grazing management. Hay or seed crops can be harvested from well-established stands which will not then deteriorate.

(b) Data for Plant Breeder: The new strain establishes rapidly under good conditions, provides a valuable bulk of early, palatable feed, and under efficient management remains for a period up to 5 years. Lines show.some variation in palatability, while susceptibility to grass-grub attack in affected districts seriously limits persistency. The development of a line with a less exacting fertility requirement appears to be warranted. 